\title{
10 Immigration and integration policies in Czechia
}

\author{
A new immigration destination \\ country in the EU ${ }^{1}$
}

Agnieszka Zogata-Kusz

\section{Introduction}

Czechia, with its over half a million foreigners, is the Visegrad country with the highest number of immigrants (Eurostat 2019). It began setting up its immigration and integration policies in 1999, since when it has regularly issued migration-related policy documents. Czech nongovernmental organisations assisting immigrants, which were able to develop thanks to the existence of an integration policy, are among the oldest in the region and are also the most active in policy advocacy at both the national and the international level, delivering sources for evidence-based policy-making (Zogata-Kusz 2018). All this gives the impression that Czech immigration and integration policies are the result of systematic elaboration. A closer look, however, reveals that, even though many positive things have been done, the policies are not as systematic, coherent and evidence-based as one might expect. This chapter presents the immigration - integration policy nexus in Czechia through the diachronic analysis of its development, focusing on the period from 1999, when two crucial legal acts were adopted and when the government issued the principles of integration policy.

Foreigners living in Czechia constitute about 5 per cent of the total population. According to data from the Directorate of the Alien Police Service, there were approximately 564,000 foreigners with permanent $(289,000)$ or longterm residence over 90 days $(275,000)$ at the end of 2018 (see Figure 10.1). Clearly, the highest number of foreigners arrived from Ukraine $(131,000)$ and Slovakia (almost 117,000). The number of foreigners has grown steadily since 1993, with only two moments of decrease: in 2000 (as a result of policy restrictions) and in 2009 (as a result of the economic crisis and policy restrictions).

Already, in the first half of the 1990s, the Czech state was regulating immigration; however, attempts at more complex policy-making in migration were only successful following the formulation of the first conceptual policy documents between 1999 and 2003. 


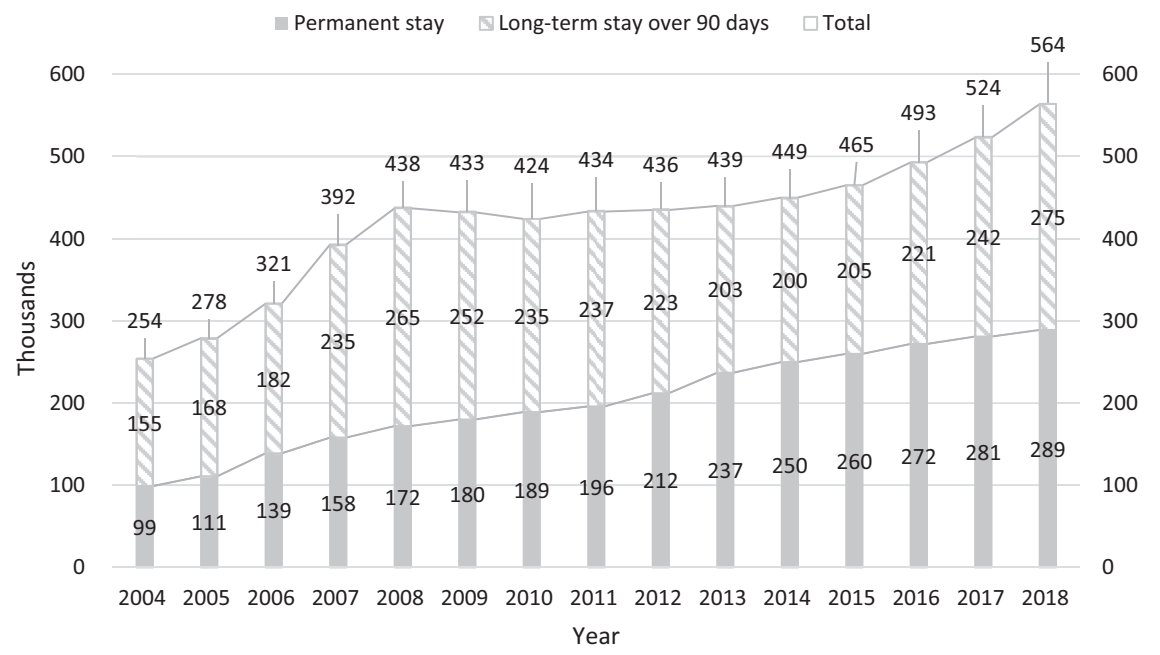

Figure 10.1 Trend in the number of foreigners in Czechia by type of residence, 2004-2018

Source: Czech Statistical Office, based on data from the Directorate of the Alien Police Service, May 2019a, www.czso.cz/csu/cizinci/cizinci-pocet-cizincu (accessed 26 July 2019)

\section{First steps in comprehensive policy-making on immigration and integration}

Between 1999 and 2003, the first steps towards more comprehensive and active policy-making in both immigration control and integration were taken. From a legal perspective, the year 1999 was crucial due to two basic legal acts which were adopted - the 1999 Act on Aliens and the 1999 Act on Asylum. To date, in their amended versions, they remain effective. ${ }^{2}$ The acts rendered the rules regarding foreigners' residence more restrictive. For instance, foreigners could no longer apply for a visa or change the purpose of their residence when they were already on the territory of the Czech state. Yet for the first time, Czech law enabled foreigners to apply for permanent residence after ten years in the country on a long-term visa. In this way, the act opened up opportunities for the legal permanent settlement of foreign nationals. This, in turn, raised the issue of the need to integrate people who, in the future, may become Czech nationals. This was an important change, especially since the numbers were rapidly increasing - from around 78,000 in 1993 to almost 229,000 by 1999 . Note, however, that a temporary consequence of the more restrictive rules of residence was a decrease in the number to 201,000 in 2000 (Czech Statistical Office 2019b). In relation to these new challenges, as well as European Union requirements for its future members, the government adopted the first policy document on foreigners' integration - the 1999 Principles of Foreigners Integration Concept in the Territory of the Czech 
Republic; the Foreigners Integration Concept (FIC) followed a year later. The first document regarding immigration policy, in the sense of immigration control Principles of Government Policy in the Area of the Migration of Foreigners - was issued only in 2003. In the 1999 Principles, the integration of immigrants was considered to be 'a natural consequence of migration'. The main rule of the government's integration policy set out in the document was the positive approach: the state took responsibility for creating the conditions for the equal participation of foreigners in society. The document highlighted, for example, the state's support for the development of relevant NGOs, creating a realistic media image of the relations between communities and immigrant rights protection on the Czech territory. Even though the policy was understood as a basic instrument for the recognition of personal endeavours, the document referred to immigrant communities several times (Government of the Czech Republic 1999). The overall idea of integration was close to a multicultural perspective. A year later, the FIC was oriented more towards the civic integration of individuals and no longer referred to immigrant communities. It concentrated mainly on the issue of dividing competencies and responsibilities between specific ministries, which were supposed to formulate plans for foreigner integration within their areas. One of the key elements of the FIC was the model of support for NGO projects, through which ministries could carry out their partial policies. Otherwise, the document was somewhat general. The main goal of Czech integration policy was to make the status of legally long-term resident immigrants similar to that of native-Czech citizens (Government of the Czech Republic 2006).

Three years later, the government adopted the Principles of Government Policy in the Area of the Migration of Foreigners (Government of the Czech Republic 2003). The principles were, however, very general (regarding, for example, the elimination of illegal immigration, support for beneficial immigration and the need for coordination) and were criticised as being too vague to have an impact on the reality (e.g. Baršová and Barša 2005; Drbohlav et al. 2005). As for the integration policy, the critics highlighted that the 2000 FIC focused on the rights of foreigners but that a crucial element - their social integration - was left out. The general nature of the 2003 document on immigration meant that Czech immigration policy was limited to the simple legal regulation of the entrance and stay of foreigners on Czech territory. Although it seemed that the documents might bring about a transformation of the Czech approach to migration from a purely legal one into a more comprehensive and political one, this proved not to be the case. Nevertheless, one positive of the FIC was that it provided a foundation for the development of nongovernmental actors engaged in integration policy implementation (based on the support for projects). NGOs provided, among other things, social and legal counselling for immigrants and their families, offered courses on the Czech language and on social and cultural orientation and work with the receiving society. Already in 2003, they created the Consortium of Migrants Assisting Organisations, which currently has 18 members (see www.migracnikonsorcium. 
$\mathrm{cz}$ ). Using their experience and hard data from day-to-day work with foreigners, Consortium members engaged in policy advocacy, providing evidence and policy implementation feedback (see Zogata-Kusz 2018).

\section{A new EU member}

A key event in recent Czech history was its accession in 2004 to the European Union. In view of Czech immigration and integration policies, this translated into the division of foreign nationals into two basic categories: EU/EEA and Swiss nationals, their family members and foreigners with permanent residence made up one category, and third-country nationals (TCNs) - 'the rest' - comprised the second. Whereas the rights of the first group resembled those of Czech citizens and were largely regulated by EU law, those of the second group were very limited. Czech immigration and integration policies mainly affected the second group.

With regard to immigration policy, which was, to a great extent, carried out on a legislative basis, after-accession amendments brought about a few important changes. Among these were the introduction of new long-term residence permits, which meant greater legal certainty for TCNs (before, only a visa was possible), the right to family reunification for TCNs (based on the implementation of an EU regulation) or the shortening of the minimum period of stay on Czech territory from ten to five years - necessary when applying for permanent residence. In 2007 , as a response to an allegedly increasing number of marriages of convenience, Czechia introduced a minimum two-year period of stay for EU nationals' family members applying for permanent residence. The implementation of EU directives meant changes in the Act on Asylum (Dohnalová 2015).

As for integration policy, a change occurred - originally perceived as important but eventually only temporary - with the transfer of responsibility for this area from the Ministry of the Interior to the Ministry of Labour and Social Affairs for the period 2004-2008.

Two years after EU accession, a new version of the Foreigners Integration Concept was adopted which brought significant changes to the further development of Czech integration policy - due to the 2006 FIC transforming the original version of the document into a more concrete policy tool. This changed the definition of integration, underlining the bi-directionality of the process and the role of the majority. It concretised the target group of integration measures (TCNs resident on Czech territory for at least one year or permanently, persons granted asylum and the receiving majority but not EU nationals) and introduced the basic preconditions for effective integration that remain in force today. These were knowledge of the Czech language, the economic self-sufficiency of the foreigner, his or her orientation in Czech society (i.e. understanding how the society and its structures function), and the relations between the foreigner and members of the majority. In this way, the 2006 version completed the concept, with a concretised social integration aspect which was missing in its original version. One lesson from the past informing these changes was that integration should go beyond the simple convergence of foreigners' rights with those of Czech nationals. It 
was recognised that it should be linked to concrete requirements regarding social integration. Additionally, development in the integration policies of other countries also influenced the changes. The document, in fact, stressed the need for the further development of integration mainstreaming, which meant considering the impacts of existing or accepted measures within other policies or legal regulations on the integration of foreigners. Therefore, the 2006 FIC defined three basic rules for the formulation of all policies in relation to foreigners. These were the principles of legal certainty, fair access and increasing rights - i.e. that foreigners would gain further rights as their length of legal residence increased (Government of the Czech Republic 2006).

Acceptance of the integration mainstreaming method should affect, inter alia, the linkages between immigration and integration policies: immigration policy should be formulated and implemented in such a way as to consider its possible effect on the integration of foreigners. The document also mentioned the nexus between the two policies by stating that 'One of the basic factors affecting the success of the integration process is the number of migrants on the territory of the given state. Integration policy should therefore form a part of the overall migration policy setting, to prevent negative effects on the integration of foreigners' (Government of the Czech Republic 2006: 6). This important sentence - expressing an awareness of the mutual influence of the two policies - was, however, only a footnote, together with the remark that Czechia lacked a comprehensive migration policy. Within a few years, policy documents would point to the link between the two policies in a more explicit way.

The main factor affecting Czech integration policy in that period was the 2004 Common Basic Principles for Immigrant Integration Policy in the EU - i.e. the comprehensive set of 11 principles adopted by the Justice and Home Affairs Council in the process of developing a common EU immigration policy. Among other important factors, there was the steadily growing number of foreigners living on the Czech territory (from 201,000 in 2000 to 278,000 in 2005) and the recognised need to support their integration in order to increase the beneficial effects of migration on the one hand and to avoid social problems on the other. Therefore, the policy-makers emphasised the necessity not only to manage integration but also to accept a proactive approach in immigration policy - i.e. to try to actively manage immigration using instruments which would attract desirable immigrants. The latter manifested itself through the launching of the project Selection of Qualified Foreign Workers (its pilot, five-year version began in July 2003), followed by opening of the Green Cards Project in 2009. The main idea of the first project was to attract qualified workers (i.e. those who had at least finished secondary school) who were interested in settling in Czechia together with their families. The selection was based on the points system. After two and half years, those registered on the project could be recommended for permanent residence following a reduced period of stay provided they were well integrated - something verified through so-called social audit (Ministry of the Interior of the Czech Republic 2003). The green cards were introduced to remove administrative obstacles and allow for the smooth filling of a job vacancy when no Czech or a foreigner with 
free access to the labour market was interested in the post. The green cards were dual in nature - a residence permit and work permit in one document. There were three types:

- $\quad$ A - for people with higher education or for key personnel (issued for up to three years);

- $\quad$ B - for foreigners employed in positions where at least an apprenticeship certificate was required (issued for up to two years); and

- $\quad \mathrm{C}$ - for foreigners employed in other positions, including the low-skilled (issued for up to two years but not extendable for low-skilled workers - Ministry of the Interior of the Czech Republic 2010).

Both projects however - and especially the first one - attracted rather more media attention than foreigners. Implementation of the Green Cards Project was, moreover, limited due to the beginning of the economic crisis. Instead of looking for ways to attract foreign workers, how to limit their number became the main consideration, the more so in that, at that moment, jobless foreigners attracted negative media and, consequently, public attention. This gave rise to the launching of a Voluntary Return Programme (which was more expensive than effective) and so-called emergency projects for municipalities facing problems with large groups of jobless foreigners. These last ones were only used by a few municipalities (later, however, emergency projects were transformed into regular projects for the support of foreigners' integration at the local level). This only proved that the policies looked better on paper than in real life. The crisis revealed the shortcomings of both projects which resulted in ad hoc and post factum actions. Despite the difficulties or, rather, because of them, Centres for Support of Integration of Foreigners (integration centres) were established in 2009, financed from EU funds. Originally launched in six regions (kraje - Czech territorial units) they were eventually in operation in all 14 regions. Most were units of the Ministry of the Interior, while others were run by NGOs or municipalities.

\section{Economy first}

2010 and 2011 marked the beginning of essential changes for Czech immigration and integration policies. In the 2010 Principles and subsequently in the 2011 resolution on the New System of Economic Migration (NSEM) based on them, the Czech government clearly presented its vision concerning the preferred volume and composition of economic immigration. Given the fact that a vast majority of migration to Czechia was economic, the documents - when implemented were to affect the lives of most foreigners living in the country. The 2010 Principles stated that economic immigration should be driven mainly by the needs of Czechia and its integration capacity, without, however, specifying what that meant (one may assume that it concerned integration through access to the labour market); its volume and composition were thought to be easy to adjust promptly to the changing economic situation and its sources could be diversified. The 
Principles then stated that there should be both circular and permanent economic immigration. They specified that qualified and highly qualified migrants should be the favoured group as far as the possibility of settlement was concerned, whereas the migration of people with low qualifications was to be based on the principle of temporariness and related to the provision of greater assistance from state authorities. Finally, the Principles referred to the need to ensure an effective integration component (in the case of long-term or permanent migration), as well as an effective return component. Simultaneously, they observed that those natural and legal persons engaged in immigrants' acceptance must also be co-responsible for immigrants' stay and departure, as well as for possible not observing of legal norms and decisions. Finally, it was felt that decision-making on the volume and composition of immigration flows should be fully dependent on the competence of Czech state authorities. The tools for managing migration should, however, be used in cooperation with the immigrant countries of origin (Government of the Czech Republic 2011a).

The Principles revealed the attitude of the Czech government towards both immigration and integration policy and the perceived nexus between them. Emphasis on the economic needs as the main factor influencing policy-making pertaining to labour migration remained in line with theoretical perspectives drawing on neoclassical economics (Brochmann 1999). Economic migration was perceived as a phenomenon that could and should be driven and economic migrants as a tool for fulfilling Czech labour-market needs. The migrants should be returned to their countries of origin when they were no longer needed (effective return component). Such a strategy revealed that the government completely ignored the experience of Western countries, which showed that it was not possible to import people when needed and export them when they were no longer considered useful (Castles 2004). As for the flexible adjustability of the migration volume and composition, the Principle conceding not only circular but also permanent migration was striking and seemed inconsistent. Note, however, that the original version of the Principle proposed by the Ministry of the Interior (MoI) declared: 'For migration for economic activities, circular migration should be preferred over permanent settlement'. It was altered only after the intervention of the Committee on Foreigners' Rights, whose members represented several NGOs (Čižinský 2011). Eventually, the government conceded the possibility of permanent settlement for economic migrants but with the reservation that it would be preferred if it were for qualified and highly qualified migrants. This differentiated approach seemed to follow the assumption that qualifications often related to high school or university degrees were directly and positively correlated with immigrants' integration capacity. This, however, did not mean that their qualifications were truly needed or would be used on the labour market. It simply meant that the more highly qualified were preferred for their potential capacity to integrate, even if they were employed in low- or middle-skill positions that were below their actual qualifications - which they might subsequently have lost qualifications. For the government, it was easier, however, to justify accepting those immigrants. 
Another issue which deserves consideration was the Principle regarding migration management being fully in the hands of the Czech authorities. As the experience of countries with longer immigration histories had proved, this should, rather, have been acknowledged as a wish expressed because of the needs of Czech society at a time when the economic crisis was still felt. The gap hypothesis, referring to the divergence between the goals of immigration policy (usually corresponding to the demand for a restrictive policy) and its eventual outputs and outcomes (Cornelius et al. 1994), is still valid as the experience of various states confirmed (see, e.g. Hollifield et al. 2014).

Implementation of the Principles may have had some important consequences for immigrant integration and its related policy. Even though one of the Principles raised the issue of an effective integration component, the stress put on the circular nature of migration, highlighting the efficiency of a return component, would eventually have produced important - and mostly negative - consequences for the integration of foreigners. Temporary residence meant the instability of their legal situation, uncertainty about their life prospects and, consequently, not only fewer opportunities to integrate but the even lower willingness of foreigners to learn the language and culture and to establish specific social networks in a country which they might soon have had to leave.

In January 2011, the government adopted a resolution known as the New System of Economic Migration to the Czech Republic. The document built on the Principles, described earlier, and represented a basis for the later transformation of both immigration and integration policies. Most measures presented in the document were introduced into the Czech legal system and practice in the following years. The main idea behind the document was to manage migration and prevent the uncontrolled inflow of foreigners - perceived as a source of inappropriate pressure on public services - and thus to hamper any negative effects on integration and integration policy. The government specified that the decisive indicator for the conditions for the entrance and stay of foreigners was the utility of migrants for Czech society, including the reduction of additional costs to the state (Government of the Czech Republic 2011a).

From the perspective of the immigration - integration policy nexus, a few issues were vital. Firstly, in a bid to simplify the administrative process, quotas were established for the various categories of residents (within a few years they were introduced for economic migrants from Ukraine, then from other selected countries - see remaining sections of this chapter). Second was the introduction of circular migration for Gastarbeiter or guestworkers, who were thus denied the opportunity to integrate (this was eventually established in 2019). Thirdly came the introduction of obligatory minimum pre-departure information and, subsequently, of post-arrival adaptation and integration courses - integration measures initiated in 2011 (Government of the Czech Republic 2011b).

The emphasis on the circularity of migration, together with the obligation for circular migrants to complete adaptation and integration courses, did not mean the state was willing to support the integration of such migrants into the hostcountry social majority, as understood in this publication. It actually meant that 
the government was attempting to reduce the risk of migration-related negative phenomena emerging.

The new system - just like the Principles it was derived from - was strongly criticised by NGOs assisting immigrants and by academics. They were concerned about the introduction of circular migration as a policy tool and the associated potential risks. As examples from other countries had shown, such regulations might eventually bring about not circular but long-term migration with invalid social and economic rights which would prevent or hamper proper integration even leading eventually to the disintegration of society (Consortium of Migrants Assisting Organisations 2018).

\section{Living together?}

After assuring, in one resolution, the fulfilling of Czech labour-market needs and the Czech government's control and management of immigration and prevention of negative phenomena related to it, the government adopted a resolution a month later which stressed the mutuality of integration and pointed to the possible beneficial effects of immigration. In February 2011, the government issued an updated version of the Foreigners Integration Concept: Living Together. One of the main changes it introduced was the broadening of a set of four basic preconditions - ensuring that foreigners were independent and selfsufficient - and transforming them into integration policy aims. This added aim concerned informedness or the acquisition of knowledge and information by migrants. The implication was that foreigners should be given information about who they could turn to for support if they needed it. At the same time, the document stressed that the policy aimed to support the receiving society in being 'open and helpful to immigrants through the measures adopted' (Government of the Czech Republic 2011b: 15). The 2011 FIC broadened the category of migrants concerned by integration measures, after which, in exceptional cases, EU nationals could also be included in the target group.

In line with the resolution released a month earlier, the 2011 FIC yet again called attention to the need to introduce minimum pre-departure information on integration in migrants' countries of origin. The aim was to help (all types of) economic migrants to avoid nasty surprises and problems following their arrival in Czechia, such as abuse by middlemen offering 'assistance' in arranging stayrelated matters - often illegally - and charging extortionate sums of money (see Čermánková and Nekorjak 2009). This pre-departure information included the conditions of stay in Czechia, warnings about the risks related to noncompliance with Czech and EU law as well as contact details of institutions and organisations assisting immigrants. The state appeared to treat it as a measure of integration policy and did not see it as an immigration policy instrument aimed at reducing the likelihood of potential emigration from the country (Brochmann 1999). Subsequently, adaptation and integration courses were supposed to provide arriving foreigners with information on their fundamental rights and obligations and a basic socio-cultural orientation - mainly regarding Czech institutions. The FIC 
2011 also introduced courses for foreigners with long-term or permanent residence permits (Government of the Czech Republic 2011b).

However, these materials and courses represented only some elements of the broadly understood and increasingly highlighted need for migrant informedness. The 2011 FIC introduced informedness as a cross-cutting component of all areas of integration, crucial for all actors concerned - the foreigners themselves, the receiving majority, as well as state institutions (Government of the Czech Republic 2011b). This attitude gave rise to a growing number of information webpages, run mainly by the Ministry of the Interior. ${ }^{3}$

Finally, the FIC version of 2011 mentioned that, although integration was based on a voluntary principle, it was unsustainable. In future, if immigrants wanted to stay longer in Czechia, some integration elements would have to become compulsory (Government of the Czech Republic 2011b). The same message was later repeated in the 2016 FIC.

The 2010 Principles and the 2011 NSEM represented a clear message regarding Czech policy towards economic migration - it would be restrictive and oriented towards the needs of Czechia and not towards foreigners' rights. Integration was understood as assimilation. The 2011 FIC contrasted greatly with these two resolutions. Despite attempts at comprehensive policy-making, the year 2011 again confirmed that Czech migration policy had still not been formulated in a coherent way.

\section{A time of panic}

The year 2015 was critical for immigration-related matters due, firstly, to the socalled European migration crisis, which some preferred to call a crisis of European migration policies (e.g. Bojadžijev and Mezzadra 2015) or a crisis of solidarity (e.g. Agustín and Jørgensen 2019). The crisis involved the extraordinarily high numbers of people seeking asylum in European countries and not primarily economic immigrants. In Czechia, rather than being a real crisis, it was a widely mediatised, broadly exaggerated issue misused by politicians trying to get into the spotlight. In fact, according to data from the Department for Asylum and Migration Policy of the Ministry of the Interior, the overall number of applications for international protection was 1,525 (about 400 more than in 2014), which was far from the record number of over 18,000 in 2001, when international migration was not attracting much public attention. ${ }^{4}$ The number of other migrants did not change dramatically - migration increased but in line with the trend over previous several years.

What was essential, however, in 2015 was not only the mediatisation of migration, ${ }^{5}$ but also the politicisation of a phenomenon which had always been apolitical in Czechia. Anti-immigrant political movements that used to be marginal - such as We Do Not Want Islam in Czechia (orig. Islam v $\check{C} R$ nechceme) - came to the fore and formed new offshoots - for example, Block against Islam (Blok proti Islamu). Established political parties also adopted an anti-immigrant rhetoric. In November 2015 as many as 81 per cent of Czechs had negative feelings in relation 
to the immigration of people from outside the EU (Eurobarometer 2015). Moreover, the politicisation went hand-in-hand with a deep securitisation of the phenomenon. All of this affected both Czech immigration and integration policy - in fact, everything relating to foreigners. The society became divided and both people who were positive about helping refugees and those who tried to stay rational and were not strongly against accepting newcomers were labelled as irresponsible welcomers (sluničkár). The situation for Czech NGOs assisting immigrants worsened to the extent that people who publicly defended the rights of foreigners became the targets of attacks - mostly in virtual space, in anonymous Internet commentaries (Zogata-Kusz 2020). Likewise, their advocacy work became much more complicated. Fewer and fewer politicians were willing to defend the rights of foreigners, since this could put their political career at risk. NGOs also had to be very careful in selecting topics to be publicised. Therefore, the 2015 crisis not only raised issues such as Czechia refusing to take part in the EU system of transferring asylum-seekers under relocation and resettlement programmes or refusing both the Global Compact on Refugees and that on Migration (only in 2018), but also strongly and negatively affected the rights of immigrants already living in Czechia.

In the middle of summer 2015, the government adopted the Strategy on Migration Policy of the Czech Republic. This was the first comprehensive policy document combining immigration control and integration issues, including matters such as asylum, return policies or combating irregular migration. The document contained seven Principles of migration strategy. For the first time, migration officially became clearly linked to the issue of security, which turned into a crosscutting component of all migration-related areas. The overall sounding of the Principles was the spirit of safety - preventing negative phenomena and risks on the one hand, and bringing benefits to the Czech economy and meeting its international commitments on the other. The strategy emphasised the importance and meaning of informedness, not only for foreigners but also for the majority. In relation to this point, the government declared that a communication strategy would be introduced as a cross-sectional tool for informing the public and other partners on migration issues (Ministry of the Interior of the Czech Republic 2015). Until December 2019, however, no such document was accepted.

Integration was one issue to which the strategy referred in the very first principle: 'The Czech Republic will adhere to its responsibility to ensure to its citizens a peaceful coexistence with foreigners and, thanks to effective integration, will prevent the development of negative social phenomena' (Ministry of the Interior of the Czech Republic 2015: 6, author's emphasis). The intention was to apply this through a proactive integration policy at local, regional and national levels, support for foreigners' integration (respecting their dignity and the prevention of security risks) and an increasing informedness among both foreigners and the Czech majority.

In light of the main topic of this book - i.e. the links between immigration policy and integration policy - the Principle regarding legal migration was significant. The strategy confirmed the validity of both of the resolutions on economic 


\section{4}

migration, presented earlier in this chapter. It also highlighted the fact that one of the policy aims was a 'desirable volume of legal migration compliant with the absorption capacities and integration measures of the Czech Republic' (Ministry of the Interior of the Czech Republic 2015: 20; author's emphasis). In other words, it was recognised that an integration policy should not only react to immigration policy but should actively influence the policy of immigration control. Where this pertained to absorption capacity, even though it was appearing for the first time in a policy document, it was a formula that the Ministry of the Interior had been using for many years at various fora, taking it to imply 'the maximum possible number of foreigners that Czech society was able to accept without radicalisation' (Kušniráková and Čižinský 2011: 503). The Ministry had long been defending measures to limit the volume of immigration - because of far-right prevention on the one hand, and foreigners' (alleged) criminality on the other. The number of foreigners sentenced for crimes was lower in the overall number of criminals than the rhetoric would suggest. Data on the most frequent countries of origin of those who committed crimes did not generally reflect those of foreigners living in Czechia. Besides, because of insufficient data, it was not possible to distinguish the share of criminals who were foreign nationals living in Czechia permanently or with long-term residence permits from that of foreigners staying in Czechia for a shorter time only (Zogata-Kusz 2017). Consequently, it was hard to assess the nexus between immigration policy and foreigners' criminality.

In autumn 2015, the Consortium of Organisations Assisting Migrants presented a Migration Manifesto that they had been drawing up for many months. The Manifesto called attention, among other things, to the need to create and implement integration policies at all levels, including the local. It reiterated the need for integration measures to apply to all immigrants regardless of their status or situation, to allow them access to legal counselling even if they were EU nationals or their stay on Czech territory was unauthorised (Consortium of Migrants Assisting Organisations 2015). Unfortunately, the timing of the publicising of the manifesto was ill-chosen. A fear of immigration was dominating the public sphere and Czech society was refusing to accept even rational and evidence-based arguments related to immigration of any type (and not only of asylum-seekers).

In 2015, the security issue was transformed and expanded; eventually the 2016 National Security Audit positioned the security aspects of migration among the main threats for the Czech state and society - indeed, on a par with issues such as the influence of foreign powers and environmental or cyber threats. The audit discussed in detail the question of migration-related dangers, highlighting both hard security threats (e.g. terrorism or organised crime) and soft ones - such as the spread of infectious diseases or cultural aspects incompatible with Czech law. In relation to the immigration - integration policy nexus, the document noted that 'From a security standpoint, and that of a peaceful coexistence of the majority society and migrants, it is the ability of migrants to integrate that directly influences the volume of immigration' (Ministry of the Interior of the Czech Republic 2016: 67). Therefore, again, although implicitly, it was stated that an effective integration policy would be vital for setting immigration policy goals. Integration is understood here as foreigners' assimilation. 
A year later, in 2016, the Foreigners Integration Concept was again updated, this time with the subheading In Mutual Respect. The main aims of the integration policy were the same as those defined by the 2011 FIC. As in this latter version, the 2016 FIC repeated that integration had been voluntary but that this approach was untenable in the long term. As the Czech state had increasingly been focusing on questions of communication and of raising awareness of foreigners as well as of the majority, it perceived information and communication as the foundation for successful integration, the prevention of xenophobia and the development of both intercultural and interreligious dialogue between communities. Together with the procedure for their realisation, the 2016 FIC produced further measures in this regard (Government of the Czech Republic 2016). Providing impartial information about immigration is challenging, however, when political entities transform it into the subject of a political battle, as in the parliamentary election campaign of 2017, when the atmosphere in Czech society lead to the first terrorist attacks in the country. ${ }^{6}$

The 2016 FIC followed the 2015 Strategy on Migration Policy, adding, however, some distinct perspectives and focuses. For instance, interestingly, the document again slightly redefined the term 'integration', pointing not only at its bi- but also its tri-directionality, recognising that integration may also be influenced to some extent by the countries of origin of foreigners. Whereas the strategy emphasised the need to ensure the security of its citizens, the 2016 FIC underlined the need to ensure the security of all inhabitants of Czechia. The attitude towards circular migration also seemed different. Contrary to previous policy documents, the authors of the updated FIC appeared to have taken notice of the examples of some Western countries, which had lived under the illusion that guestworkers would return to their home countries. In the part presenting the procedure for implementation, the 2016 FIC admitted that, in the long term, the increasing percentage of permanent residence permits in the overall number of permits was a positive trend. It had a favourable effect on the integration process, since permanent residence caused the situation of foreigners to converge with that of citizens, regarding, for example, the labour market, health insurance or access to social benefits (Government of the Czech Republic 2016).

All of this was remarkable, given the emphasis that the New System of Economic Migration placed on the circularity of migration. It proved that various conflicting tendencies had been affecting Czech policy. In spite of the existence of conceptual documents, the actual vision of immigration and integration policies was ambiguous, however.

\section{The current situation}

Most foreigners living in Czechia do not need work permits, either because they are citizens of the EU/EEA and Switzerland or because of exceptional circumstances that grant them free access to the labour market. According to data from the Ministry of Labour and Social Affairs, for example, in 2018 Czech labour offices were informed of the employment of 366,000 citizens of the EU/EEA and 
Switzerland, and of as many as 125,000 other foreigners who did not need a work permit. $^{7}$

Foreigners with limited access to the Czech labour market mostly use the socalled Employee Cards, which replaced the Green Cards in 2014. In its basic form, an Employee Card is dual in nature - i.e. it combines residence permit and work permit. It is mostly issued for the duration of the working contract but for a maximum length of two years. Foreigners may extend it repeatedly. According to data from the Ministry of Labour and Social Affairs, at the end of 2018 there were over 45,000 Employee Card-holders (at the same time, the total number of foreigners holding a valid work permit issued in relation to long-term residence permits for a different purpose was over 31,000 ). To increase the capacity of offices issuing Employee Cards and to make the process more manageable, the Ministry of the Interior launched a few special regimes. Quotas for Employee Cards for selected countries can now be set. These are Ukraine - for which the quota of newly issued cards per year increased in 2018 from 9,600 to 19,600 (Confederation of Industry of the Czech Republic 2018) - then the Philippines and Mongolia (quotas of 1,000 each) and Serbia - 2,000 Employee Cards per year (Ministry of Industry and Trade of the Czech Republic 2018). This illustrates that the state is attempting to implement the principle of diversification of immigration sources.

Lessons learned during the economic crisis - when, in some municipalities, the presence of larger groups of foreigners disrupted the capacity of the infrastructure and resulted in social discontent - were used in setting up the rules for special regimes. Employers making a collective application for more than 50 (in case of Regime Ukraine) or 30 (in case of Regime Other States) employees are now supposed to cooperate with the relevant Centre for Support of the Integration of Foreigners and the municipal authorities and to discuss their intentions with their current employees. In other words, the idea is to link immigration and integration policies and support economic migrants' integration - or at least limit the risks related to unpreparedness and a shortage of information. In reality, it often ends with 'solemn declarations' or the circumvention of the requirement by applying several times for a smaller number of employees, rather than once for more. This is, for example, the case of a company situated in Moravia region that employs over 200 foreigners but does not cooperate with anyone regarding the group - an outstanding example of a policy gap.

In addition to Employee Cards, highly qualified professionals may work in Czechia if they are in possession of a Blue Card. Their number is small: according to data from the Ministry of Labour and Social Affairs, at the end of 2018 it was 590 persons (including 442 in Prague). The main obstacle when applying for the card is not the qualification ${ }^{8}$ but the salary. The gross monthly or annual salary must be equal to at least one and a half times the average gross annual salary set by the Ministry of Labour and Social Affairs which, for the period from April 2019 to April 2020, is over 382,000 CZK - i.e. almost 15,000 EUR (Ministry of Labour and Social Policy 2019). The recruitment of highly skilled employees - whether holders of Employee or of Blue Cards - is considerably easier thanks to Project Ukraine and Project India. In 2016, the quotas determined for these two projects was 500 (Ministry of Industry and Trade of the Czech Republic 2016). 
Finally, many economic migrants stay in Czechia for business. ${ }^{9}$ As of December 2018, data from the Ministry of Industry and Trade showed that almost 90,000 foreigners held a valid trade licence, 56,000 of whom were third-country nationals (nearly 22,000 were Ukrainians; slightly fewer, Vietnamese). Family reunification is possible after at least 15 months of residence in Czechia (in general) or six months (for those with an Employee Card).

The 2019 amendment introduces several significant changes to the existing immigration rules. These concern, among other things, the quotas for economic inflows, circular migration and integration (Act amending Act No. 326/1999 Coll., on the Residence of Aliens in the Territory of the Czech Republic 2019).

The amendment installs a system of quotas for long-term stays connected to Employee Cards as well as for long-term visas for the purpose 'business'. The hope is that it will help to improve the current situation, in which quotas are in fact imposed but in an unpredictable way. Now - as the explanatory statement explains - quotas should be set in tripartite negotiations between employers, trade unions and the government, and should take into consideration - among other things - integration capacities (Chamber of Deputies of the Parliament of the Czech Republic 2018). Again, it is not explained what integration capacities mean. Besides - as the Consortium of Organisations Assisting Migrants has pointed out - it is nowhere specified how market needs, which are the basis for the quotas, should be determined. Moreover, the quotas will only concern Employee Card holders and long-term stays for the purpose of entrepreneurship, but not, for example, seasonal employment (Consortium of Migrants Assisting Organisations 2018).

In relation to that since September 2019, the above-mentioned special regimes and projects were transformed into three governmental programs. Currently nationals of all third countries may apply for Employee Cards within the programs: Highly-skilled Employee as well as Key and Scientific Personnel. Nationals of nine (instead of only four) selected countries may also make their applications within the program Qualified Employee. This regards nationals of Belarus, Montenegro, the Philippines, India, Kazakhstan, Moldova, Mongolia, Serbia and Ukraine. Foreigners may be classified to the programs only through their employers to-be who had been classified for the programs. A specific and controversial - thing related to the program is that a foreigner may change employer after only six months since the decision on the Employee Cards became final. This is to stop pulling over foreigners between the employers in the situation of labour force shortages. For the whole period of the contract, the employee will have to receive 1.2 of the guaranteed wage. Given the fact that before applying for foreign employees, the employers have to do a so-called labour market test (i.e. to ensure that it is not possible to find an employee from among the people who do not need any work permits), this measure should protect Czech nationals from salary reduction. The amendments maintain the requirement that employers making a collective application for more than 50 qualified employees have to deliver statement of a mayor of the municipality in which those people will live. The statement has to include explicit agreement for that. Besides, as before, the employers have to deliver a solemn declaration that they discussed their intentions 
with their current employees. Cooperation with the Centre for Support of the Integration of Foreigners is not explicitly required anymore (Ministry of the Interior of the Czech Republic 2019).

In addition to quotas, the amendment introduces a one-year Extraordinary Work Visa (EWV), with no possibility of extending it or changing to another type of residence or family reunification. The uniqueness of the visa lies in the fact that foreigners can apply for it only after the government has stated which professions or branches it will cover, the maximum number of applications and the nationality of foreigners which the EWV would include (Chamber of Deputies of the Czech Republic 2018).

For a number of years, the Ministry of the Interior has been announcing the introduction of circular migration. To date, however, Czechia has had a policy in which economic migration was based on long-term permits (recently mainly Employee Cards) and the state could regulate foreigners' length of stay, issuing positive or negative decisions on extensions. Currently it implies that Czechia is orienting its policy towards the Gastarbeiter model, as the country attempts to get the most out of migration at the lowest cost. This is how many politicians perceive circular migration, forgetting about the warning experience of Western countries which - to paraphrase the famous sentence of the Swiss novelist Max Frisch - wanted just hands but then realised that people came too. Germany is a striking example (see Bade 2004). EWV means that soon there will be secondcategory people. It is not expected that these people will integrate because they are not expected to stay. As in Western countries, one may suppose that they will stay, however, illegally and with no rights. The impossibility of extending the visa or changing it to some other type of residence permit means that, even after many years of living in Czechia, they will be able neither to bring their families nor to apply for permanent residence. The measure unambiguously clashes with the concept of integration and integration policy. Besides, as the lawyers of the Consortium of Migrants Assisting Organisations (2018) have pointed out, it is also anti-family, anti-employee (uncertainty for the future, very limited social rights) but also anti-employer (after one year they will lose an educated and vetted employee) and non-respectful of EU law - the 2011 Single Permit Directive. Altogether, it runs counter to the established system and is ill-conceived.

It is striking how the Czech authorities seem to be confident that they will better manage something that other states have not been able to do and which negatively affected their social and economic structures (Castles 2004; Zolberg 1989). Treating circular migration as a tool for solving labour market problems may lead to 'boiled frog syndrome' - the negative effects of circularity may become visible, when it is already too late to reverse them.

The introduction of circular migration is in contrast with attempts to reinforce integration policy by adding a chapter to the Act on Aliens devoted to integration. Until now, integration policy has been shaped by general and nonbinding documents. The only integration component that has been compulsory is the Czech language test at the level of A1 for applicants for a permanent residence permit. Including integration in binding law is, therefore, an essential step in Czech 
policy development (Chamber of Deputies of the Parliament of the Czech Republic 2018). Given the significance of integration underlined by lawmakers and the fact that it is a cross-cutting topic overlapping with many areas - therefore the EU stresses the meaning of integration mainstreaming - it is surprising that the chapter in the Act on Aliens consists of only two articles. One embeds the existence, functioning and financing of Centres for Supporting the Integration of Foreigners in law and the other concerns the introduction of compulsory adaptation and integration courses. Even the term integration does not gain its legal definition. All in all, it is modest and partial and does not indicate a complex approach to the issue.

The reinforcement of integration centres is an important systemic and stabilising element. Since the amendment, the centres will be grounded in the legal act and their budgets will be steadier and independent of financing from European projects. Their target group will broaden, since they will be entitled to also provide services to EU nationals. The scope of their tasks will stay the same but their focus will move towards the organisation of integration and adaptation courses, which will be obligatory for third-country nationals with long-term or permanent residence permits. As highlighted in Article 155b of the amended act, the aim of the one-day courses is the same as it currently is: to introduce foreigners to their rights and obligations and to the local context, practices and Czech values (Act amending Act No. 326/1999 Coll., on the Residence of Aliens in the Territory of the Czech Republic 2019). Foreigners will have to cover the cost of the obligatory course and this is one of the things that NGOs working with migrants criticise. Another thing is that given the fact that the number of immigrants has been rising recently, with between 15,000 and 30,000 per year, the question arises whether integration centres will be prepared to launch courses from January 2021.

\section{General findings}

At first glance, it seems that Czech immigration and integration policies have been developing in a systematic, well-organised way since 1999. A closer look overturns this view. It is important to recognise that many positive things have been done concerning integration policy - e.g. shortening the period of stay for permanent residence from ten to five years, increasing and disseminating information, allowing family reunification, establishing integration centres and supporting the development of migrant-assisting NGOs. In spite of this, the overall policy towards migration is inconsistent, uncoordinated, unsystematic, mainly representing a transposition of EU law that some authors have already noted (e.g. Dohnalová 2015; Drbohlav et al. 2010; Kušniráková and Čižinský 2011). The relevant ministries, as Pořízek (2018) points out, are insufficiently involved in policy implementation. The same applies to the still-inadequate involvement of municipalities. One result of the situation is the delay in the implementation of integration measures and a number of unsolved problems such as the health insurance of TCNs. The policy is unstable and often changes, which Kušniráková (2014) ascribed a few years ago to the apolitical nature of migration policy-making, when the rules were set by government authorities - predominantly the Ministry of the 
Interior - and political parties felt no commitment to or responsibility for it. Currently, the policies are no longer apolitical. Unfortunately, emotion-driven thinking about immigration and immigrant rights leads to an acceptance of rules that do not contribute to effective immigration control and integration.

Diachronic analysis of the development of the two policies reveals that, for many years, immigration policy and integration policy were treated as two separate issues. If the documents make the connection between them, the formulations that are used point, instead, to the precedence of immigration policy over integration policy. This latter policy is referred to as the one that follows, reacts to immigration rules, is a tool of immigration policy or must be prepared for the incoming immigration situation. This is striking, given the fact that the 2010 Principles stated that 'the volume and structure of legal migration is to be determined by the need of the Czech economy and the integration capacity' of the Czech state. The 2015 Strategy similarly set as one of the goals an 'advisable volume of legal migration, compliant with the absorption capacities and integration measures of the Czech Republic'. Therefore, one can see that the relation between the two policies should not be inherently unidirectional.

The aim of introducing the integration mainstreaming method - as an adaptation of EU principles - was to establish more connections between the two policies (and many others). The reality showed that immigration and integration policies were inconsistent with each other. One striking example was the project on the Selection of Qualified Foreign Workers ${ }^{10}$ versus the policy towards foreigners graduating from Czech senior schools and universities. As Kušniráková and Čižinský (2011) remind us, the state devoted a great amount of money to the project. At the same time, foreign graduates of Czech schools and universities in other words, people with great integration potential - were highly unlikely to remain in Czechia.

Ill-conceived measures were also taken, driven probably by the desire to send a message to the Czech majority. This pertains to the widely mediatised Voluntary Return Programme. As Kušniráková and Čižinský (2011) noted, in 2009 the Czech state spent 100 million crowns (i.e. approximately 4 million EUR) to return over 2,000 foreigners to their countries of origin (1,300+ to Mongolia). In the same year, 19,000 foreigners arrived in Czechia but the state spent less than a quarter of that amount on an integration policy covering them and the more than 430,000 other immigrants already residing in the country.

Despite some positive changes one may doubt about the overall development of migration-related policies. Even though the stabilisation of integration centres is a positive step, the issue of extraordinary working visas raises serious misgivings. Moreover, the attitude towards integration that the new amendment reveals proves that statements about the influence of integration policy on that of immigration are only declaratory.

This all proves that Czech immigration and integration policies have not thus far been coordinated or systematic. Even the fact that, for many years, all issues regarding foreigners were the responsibility of the Ministry of the Interior is not helpful in this regard. It seems that immigration policy documents understand 
integration in an entirely different way to those of integration policy, despite the fact that both types are produced by one ministry - the Ministry of the Interior. The Foreigner Integration Concept refers to integration in terms of the bi-directionality of the process, the mutually beneficial effects of living together, the feeling of belonging and co-responsibility for common issues and mutual communication. It stresses the protection of rights and the safety of all inhabitants of Czechia. Integration is a key to social cohesion and economic, social and cultural development (see Government of the Czech Republic 2016: 17). In contrast, immigration policy documents - although in an implicit way - define integration only in terms of the prevention of negative phenomena either produced by foreigners or - in relation to them - by the majority population and emphasise the need to ensure the safety of all its citizens. The stress laid on control and security indicates that the thinking of the authors of immigration policy documents is based on premises influenced by neorealism. As Weiner $(1993,1995)$ notes, making links between migration and economic and cultural threats may, consequently, negatively affect the ability of societies to absorb immigrants and supports the image of them as dangerous aliens. The price of this is the radicalisation of society, the rise of xenophobia and extremism - as the case of the first terrorist attacks prove.

The relation between Czech immigration and integration policies is unbalanced with the first taking precedence over the second. This is a result, for instance, of immigration rules having legal anchoring (when integration policy has been driven only by nonbinding documents and is dispersed) and from the position of the Ministry of the Interior (also responsible for security, internal control and the police) in policy-making.

\section{Connecting points}

Despite declarations pointing out the need to consider integration policy in immigration policy-making, this has not occurred. Immigration rules do not build on integration policy, and integration policy documents do not produce recommendations for immigration policy. A closer look, however, allows us to identify a few ways in which the policies affect each other.

The influence of immigration policy on integration policy is the more visible and explicit. Legal and administrative obstacles put in the way of foreigners willing to extend their stay in Czechia are serious impediments to the implementation and development of integration measures concerning them. Overrestrictive immigration policy invalidates integration policy. The uncertain situation of foreigners consequently hampers both their possibilities and willingness to learn the Czech language and culture and to build connections with the majority population.

The same applies to obstacles put in the way of foreigners in other areas. Shortages in integration mainstreaming eventually mean that the state itself is not participating sufficiently in integration. If Czech integration policy documents define integration as a bi-directional process, the state's responsibility is to create the right conditions for foreigners' inclusion and to support their active participation 
in social life - too restrictive immigration policy (as well as limited access to health insurance or social rights) means that the state is not creating them.

On the contrary, the liberalisation of immigration policy - for example, through reducing the number of years required for permanent residence from ten to five, or allowing dual citizenship - binds foreigners to their host country, stabilises their legal situation and may support their integration.

The same applies to the implementation of the 2010 Principle, which says that persons engaged in immigrants' acceptance must be co-responsible for activities in the area of migration and integration - later translated into the obligatory engagement of employers in migrant integration while making collective applications for foreign employees. If this kind of measure were indeed carried out, it may represent an interface between immigration and integration policies.

Integration policy also affects immigration policy, although in an indirect way. I perceive the emphasis on informedness as the key aspect of that relation and its connecting of the two policies. Besides, in endeavouring to increase foreigners' informedness at various stages of their immigration process - including their preimmigration - integration policy may potentially affect which type of residence (or the purpose of their stay) they apply for, as well as its legality.

State or municipal support for social and legal counselling carried out by NGOs and integration centres may affect the legality of foreigners' stay, as well as the volume and composition of those who decide to extend their residence in Czechia and/or to bring in their families (and whether they are able to make an application). The organisation of language and socio-cultural courses may not only support foreigners' integration but may also increase their opportunity for permanent residence or naturalisation. This is, however, more a matter of the influence of integration policy on immigration itself than on immigration policy.

The potential of using integration policy as one of the determinants of immigration policy is not exploited nearly enough. Even though some NGOs assisting immigrants do engage in policy advocacy and offer policy-makers their findings following integration and immigration policy implementation as well as the possibility of carrying out evidence-based policy-making, most do not avail themselves of this opportunity.

To conclude, I argue that Czech integration policy still mainly follows on from immigration policy rather than influences it. The influence of integration policy may be declaratory but the reality is that any influence is merely indirect. However, immigration policy affects both integration policy (to a lesser extent) and integration itself (to a greater extent).

\section{Notes}

1 Acknowledgements: This article was supported by the Palacky University Olomouc Internal Grant Agency CMTF 2019010.

2 The Act on Aliens was amended 56 times.

3 For example, www.cizinci.cz, www.imigracniportal.cz and www.vitejtevcr.cz.

4 Positive decisions on asylum were made in 71 cases (of whom 29 regarded Syrian nationals); in 2016 the figure was 148 (101 regarding Iraqi nationals), in 2017, 
29 - mostly Ukrainian nationals (Department for Asylum and Migration Policy, Ministry of the Interior 2018).

5 This was already the case for the period 2008-2009 when, during the financial crisis, many foreign workers lost their jobs.

6 In June and again in July 2017 a Czech retiree, Jaromír Balda, attacked trains by felling trees onto the tracks to derail them. He left leaflets which included the phrase Allah Akbar and made anti-Czech threats so as to leave no doubt that the attack was carried out by a Muslim immigrant (he was sentenced for terrorism in 2019).

7 The total number of immigrants about whom information is given and the number of permits mentioned in this section is higher than the number of foreigners because the latter may hold both a permit and a trade licence and because employers have to inform labour offices about every single contract - even part-time ones - given to foreigners.

8 To have completed a university or a vocational education, the duration of which was at least three years, is sufficient.

9 Foreigners may also undertake seasonal work. In line with EU law, they may then use the so-called Intra-Company Employee Transfer Card, as well as the European Union Member-State Intra-Company Employee Transfer Card.

10 The project was discontinued at the end of 2010. Between its launch in 2003 until its demise, there were 1,964 qualified foreign workers in total who participated in the project, together with their approximately 1,800 family members. Almost 1,000 were eventually granted permanent residence in Czechia (Ministry of the Interior of the Czech Republic 2010).

\section{References}

Act amending Act No. 326/1999 Coll., on the Residence of Aliens in the Territory of the Czech Republic (2019). Available at www.psp.cz/sqw/sbirka.sqw?O=8\&T=203 (accessed 22 August 2019).

Agustín, Ó.G. and Jørgensen, M.B. (2019) 'From refugee crisis to a crisis of solidarity?', in Solidarity and the 'Refugee Crisis' in Europe. Cham: Palgrave Pivot, pp. 1-22. doi: 10.1007/978-3-319-91848-8.

Bade, K. (2004) Evropa v pohybu: evropské migrace dvou staletí. Prague: Nakladatelství Lidové noviny.

Baršová, A. and Barša, P. (2005) Přistěhovalectví a liberální stát: imigrační a integrační politiky v USA, západní Evropě a Česku. Brno: Masaryková University, Mezinárodní politologický ústav.

Bojadžijev, M. and Mezzadra, S. (2015) “"Refugee crisis” or crisis of European migration policies?', Focal Blog, 12 November. Available at www.focaalblog.com/2015/11/12/ manuela-bojadzijev-and-sandro-mezzadra-refugee-crisis-or-crisis-of-europeanmigration-policies/ (accessed 24 July 2019).

Brochmann, G. (1999) 'The mechanism of control', in Brochmann, G. and Hammar, T. (eds) Mechanism of Immigration Control: A Comparative Analysis of European Regulation Policies. Oxford: Berg, pp. 1-27.

Castles, S. (2004) 'Why migration policies fail', Ethnic and Racial Studies, 27(2): 205227. doi: $10.1080 / 0141987042000177306$.

Čermáková, D. and Nekorjak, M. (2009) 'Ukrainian middleman system of labour organization in the Czech Republic', Tijdschrift voor Economische en Sociale Geografie, 100(1): 33-43. Available at https://doi.org/10.1111/j.1467-9663.2009.00505.x (accessed 24 July 2019).

Chamber of Deputies of the Parliament of the Czech Republic (2018) Vládni návrh zákona, kterým se méní zákon č. 326/1999 Sb., o pobytu cizinců na Územi České 


\section{Agnieszka Zogata-Kusz}

republiky a o změně některých zákonů, ve znění pozdějšich predpisů, a dalši souvisejicí zákony. Chamber of Deputies Print No. 203. Available at www.psp.cz/sqw/text/tiskt. sqw? $=8 \& C T=203 \& C T 1=0$ (accessed 24 July 2019).

Čižinský, P. (2011) 'Proč je tzv. "nový systém ekonomické migrace” nepřijatelný!' [PowerPoint presentation]. Prague: Multikulturní centrum Praha. Available at migraceonline. cz/doc/Cizinsky_prezentace.ppt (accessed 24 July 2019).

Confederation of Industry of the Czech Republic (2018) Vláda navýśila kvóty $v$ Režimu Ukrajina. 1 February. Available at www.spcr.cz/muze-vas-zajimat/pravniinfoservis/11555-vlada-navysila-kvoty-v-rezimu-ukrajina (accessed 24 July 2019).

Consortium of Migrants Assisting Organisations (2015) Migrační manifest nevládních organizaci pracujicich s migranty v České republice 2015. Available at http://www. migracnimanifest.cz/cz/index.html (accessed 24 July 2019).

Consortium of Migrants Assisting Organisations (2018) Právní analýza vládního návrhu novely zákona o pobytu cizinců2018 (Sněmovní tisk č. 203). Available at www. migracnikonsorcium.cz/wp-content/uploads/2018/10/Novela-ZPC-2018_-pr\%C3\% A1vn\%C3\%AD-anal\%C3\%BDza_FINAL.pdf (accessed 24 July 2019).

Cornelius, W.A., Martin, P.L. and Hollifield, J.F. (1994) Controlling Immigration: A Global Perspective. Stanford, CA: Stanford University Press.

Czech Statistical Office (2019a) Trend in the Number of Foreigners in the CR by Type of Residence: 2004-2018 (31.12). Available at www.czso.cz/csu/cizinci/cizinci-pocetcizincu (accessed 24 July 2019).

Czech Statistical Office (2019b) Data-počet cizinců. Trvale a dlouhodobě usazení cizinci $v \check{C} R$ v letech 1985-2018 (k 31. 12.). Available at www.czso.cz/csu/cizinci/4-ciz_pocet_ cizincu\#cr (accessed 24 July 2019).

Department for Asylum and Migration Policy, Ministry of the Interior (2018) R22 Azyl udělen - počet rozhodnutí v jednotlivých letech (1. 1. 1997-31. 12. 2017). Available at www.czso.cz/csu/cizinci/data-mezinarodni-ochrana\#cr (accessed 22 August 2019).

Dohnalová, E. (2015) Interkulturní mediace a interkulturni práce - nástroje sociální práce $v$ oblasti integrace migrantů. Prague: Charles University, Philosophical Faculty, Rigorosum thesis. Available at https://dspace.cuni.cz/handle/20.500.11956/67687 (accessed 24 July 2019).

Drbohlav, D., Horáková, M. and Janská, E. (2005) 'The Czech Republic', in Niessen, J., Schibel, Y. and Thompson, C. (eds) Current Immigration Debates in Europe. A Publication of the European Migration Dialogue. Brussels: Migration Policy Group, pp. 65-99. ISBN 2-930399-18-X.

Drbohlav, D., Medová, L., Čermák, Z., Janská, E., Čermáková, D. and Dzúrová, D. (2010) Migrace a (i)migranti v Česku: kdo jsme, odkud přicházíme, kam jdeme? Prague: Sociologické nakladatelství (SLON).

Eurobarometer (2015) Standard Eurobarometer 84 (First Results). Autumn 2015. Available at http://ec.europa.eu/commfrontoffice/publicopinion/index.cfm/Survey/getSur veyDetail/instruments/STANDARD/surveyKy/2098 (accessed 24 July 2019).

Eurostat (2019) Obyvatelstvo podle státního občanství - Cizinci (Czech version). Available at http://apl.czso.cz/pll/eutab/html.h?ptabkod=tps00157 (accessed 24 July 2019).

Government of the Czech Republic (1999) Usnesení Vlády České republiky ze dne 7. Července 1999 č. 689 o Zásadách koncepce integrace cizincủ na územi České republiky a o prípravě a realizaci této koncepce. Available at https://kormoran.vlada.cz/usneseni/ usneseni_webtest.nsf/0/C0665259AEE14CA4C12571B6006D8A70 (accessed 24 July 2019). 
Government of the Czech Republic (2003) Usneseni vlády České republiky ze dne 13. ledna 2009 č. 55 k účinnosti Koncepce integrace cizinců na území české republiky a Zásady migrace cizinců. Available at https://mintegration.zcu.cz/porozumet-migraci/ rozcestnik-klicovych-norem-a-strategickych-dokumentu/rozcestnik-klicovych-norema-strategickych-dokumentu/ (accessed 24 July 2019).

Government of the Czech Republic (2006) Usnesení vlády České republiky ze dne 8. února 2006 č. 126 Koncepce integrace cizinců v roce 2005 a její dalši rozvoj. Available at www.mvcr.cz/migrace/clanek/zakladni-dokumenty-k-integracni-politice-ke-stazeni. aspx (accessed 24 July 2019).

Government of the Czech Republic (2011a) Usneseni Vlády České republiky ze dne 19. ledna 2011 č. 48 o opatřeních k Řizeni ekonomické migrace, ochraně práv osob migrujicich za prací a realizaci návratů. Available at www.google.com/url?sa $=\mathrm{t} \& \mathrm{rct}=\mathrm{j} \& \mathrm{q}=\&$ esrc $=$ s\&source $=$ web\&cd $=4 \& v e d=2$ ahUKEwj-ttHczvHiAhXObFAKHeK4DkoQFjAD egQIABAC\&url=https\%3A\%2F\%2Faa.ecn.cz\%2Fimg_upload\%2F224c0704b7b774 6e8a07df9a8b20c098\%2FNNEM.doc\&usg=AOvVaw3V4Ybnm3F5Ci2MdYJRfm4a (accessed 24 July 2019).

Government of the Czech Republic (2011b) Usneseni Vlády České republiky ze dne 9. února 2011 č. 99 k aktualizované Koncepci integrace cizinců 2011 - Společné soužití. Available at www.mvcr.cz/migrace/clanek/zakladni-dokumenty-k-integracni-politiceke-stazeni.aspx (accessed 24 July 2019).

Government of the Czech Republic (2016) Usneseni vlády České republiky ze dne 18. ledna 2016 č. 26 k aktualizované Koncepci integrace cizincủ 2016 - Ve vzájemném respektu. Available at www.mvcr.cz/migrace/clanek/zakladni-dokumenty-k-integracnipolitice-ke-stazeni.aspx (accessed 24 July 2019).

Hollifield, J.F., Martin, P.L. and Orrenius, P.M. (2014) Controlling Immigration: A Global Perspective. Stanford, CA: Stanford University Press.

Kušniráková, T. (2014) 'Is there an integration policy being formed in Czechia?', Identities: Global Studies in Culture and Power, 21(6): 738-754. doi: 10.1080/1070289X. 2013.828617.

Kušniráková, T. and Čižinský, P. (2011) 'Dvacet let české migrační politiky: Liberální, restriktivní, anebo ještě jiná?’, Geografie, 116(4): 497-517.

Ministry of Industry and Trade of the Czech Republic (2016). Pilotni projekt: Zvláśtni postupy pro vysoce kvalifikované zaměstnance z Ukrajiny a Indie. 15 June. Available at www. mpo.cz/cz/zahranicni-obchod/ekonomicka-migrace/pilotni-projekt-zvlastni-postupy-provysoce-kvalifikovane-zamestnance-z-ukrajiny - 170394/ (accessed 26 July 2019).

Ministry of Industry and Trade of the Czech Republic (2018) Režim ostatni státy-ekonomická migrace. 16 March. Available at www.mpo.cz/cz/zahranicni-obchod/ekonomickamigrace/rezim-ostatni-staty - 235549/ (accessed 26 July 2019).

Ministry of the Interior of the Czech Republic (2003) Zpráva o situaci v oblasti migrace a integrace cizinců na územi České republiky v roce 2003. Available at www.mvcr.cz/ migrace/clanek/rocni-zpravy-o-situaci-v-oblasti-migrace-a-integrace-cizincu-v-ceskerepublice-za-roky-2001-2017.aspx (accessed 26 July 2019).

Ministry of the Interior of the Czech Republic (2010) Zpráva o situaci v oblasti migrace a integrace cizinců na územi České republiky v roce 2010. Available at www.mvcr.cz/ migrace/clanek/rocni-zpravy-o-situaci-v-oblasti-migrace-a-integrace-cizincu-v-ceskerepublice-za-roky-2001-2017.aspx (accessed 26 July 2019).

Ministry of the Interior of the Czech Republic (2015) Strategie migračni politiky České republiky. Available at www.mvcr.cz/clanek/strategie-migracni-politiky-cr.aspx (accessed 26 July 2019). 
Ministry of the Interior of the Czech Republic (2016) National Security Audit. Available at www.mvcr.cz/cthh/clanek/audit-narodni-bezpecnosti.aspx (accessed 26 July 2019).

Ministry of the Interior of the Czech Republic (2019) Kvóty pro ekonomickou migraci \& Programy schválené vládou za účelem dosaženi ekonomického př́nosu pro ČR Available at https://www.mvcr.cz/clanek/kvoty-pro-ekonomickou-migraci-programy-schvalenevladou-za-ucelem-dosazeni-ekonomickeho-prinosu-pro-cr.aspx (accessed 10 October 2019).

Ministry of Labour and Social Policy (2019) 104 Sděleni Ministerstva práce a sociálních věcí ze dne 29. března 2019 o výši prüměrné hrubé roční mzdy v České republice za rok 2018 pro Účely vydáváni modrých karet podle zákona č. 326/1999 Sb., o pobytu cizincu na Územi České republiky a o změně některých zákonů, ve znění pozdějšich předpisů. 1 May. Available at https://portal.mpsv.cz/sz/obecne/prav_predpisy/akt_zneni/sdeleni_ phm (accessed 26 July 2019).

Pořízek, P. (2018) “"Lesk a bída” integrace cizinců pohledem vládních koncepcí integrace cizinců (s využitím kazuistik z praxe veřejného ochránce práv', Acta Universitatis Carolinae - Iuridica, 2: 49-72. doi: 1014712/23366478.2018.5.

Weiner, M. (1993) International Migration and Security. Boulder, CO: Westview Press.

Weiner, M. (1995) The Global Crisis: Challenge to State and to Human Rights. New York: HarperCollins.

Zogata-Kusz, A. (2017) 'Zapobieganie przestępczości cudzoziemców w Republice Czeskiej’, in Klaus, W., Laskowska, K. and Rzeplińska, I. (eds) Przestępczość cudzoziemców. Aspekty prawne, kryminologiczne i praktyczne. Warsaw: Wydawnictwo Naukowe, pp. 512-551.

Zogata-Kusz, A. (2018) 'Non-governmental organisations and policy advocacy in relation to migration: The case of Poland and Czechia'. Paper given to the Jean-Monnet Chair in Migration Conference: Migration - The Challenge of European States. Trnava: University of Saints Cyril and Methodius, Faculty of Social Sciences, pp. 26-27, April.

Zogata-Kusz, A. (2020) 'Jedna z nejvíce hated job v ČR? Práce s migranty a reakce okolí', Časopis Sociální práce/Sociálna práca, 1/2020 (in print). Available at www.socialni prace.cz/index.php?sekce $=2$.

Zolberg, A.R. (1989) 'The next waves. Migration theory for a changing world', International Migration Review, 23(3): 403-430. 